\title{
Association of Nurturing at Daycare with Lower Risk of Suspected Emotional and Behavioral Disorders in 3-6 Year-old Children
}

\author{
I. Gusti Ayu Trisna Windiani*, Anlidya Permatasari Gunawijaya, \\ I. Gusti Agung Ngurah Sugitha Adnyana, Soetjiningsih \\ Department of Child Health, Medical Faculty of Udayana University, Denpasar, Indonesia
}

Email address:

trisnawindianidr@yahoo.co.id (I. G. A. T. Windiani), anlidyapg@gmail.com (A. P. Gunawijaya),

sugad168@yahoo.com (I. G. A. N. S. Adnyana),prof_soetji@yahoo.com (Soetjiningsih)

${ }^{*}$ Corresponding author

\section{To cite this article:}

I. Gusti Ayu Trisna Windiani, Anlidya Permatasari Gunawijaya, I. Gusti Agung Ngurah Sugitha Adnyana, Soetjiningsih. Association of Nurturing at Daycare with Lower Risk of Suspected Emotional and Behavioral Disorders in 3-6 Year-old Children. American Journal of Pediatrics. Vol. 6, No. 2, 2020, pp. 117-120. doi: 10.11648/j.ajp.20200602.19

Received: February 12, 2020; Accepted: February 26, 2020; Published: March 10, 2020

\begin{abstract}
Emotional and behavioral disorders (E/BD) is a serious problem affecting the development, productivity, and quality of life of children. There were many risk and protective factors associated with this disorder, including caregiving method. The aim of this study is to prove the association of nurturing at daycare with suspected E/BD in 3-6 years-old children. This analytical cross sectional study was conducted in August 2018 at private preschools in Denpasar, Bali. Data were obtained from parents' interview and Kuesioner Masalah Perilaku dan Emosional (KMPE). Other factors investigated were age, gender, main caregiver, main caregiver's education, parents' income, and number of siblings. Total sample in this study was 70 children, mean age 4.46 years-old. Out of 70 children, 38 children (54.3\%) had suspected E/BD. Twenty-six children (37.1\%) was nurtured at daycare. There was significant association of nurturing at daycare with suspected $\mathrm{E} / \mathrm{BD}(\mathrm{p}<0.001)$. Logistic regression analysis revealed significant association of nurturing at daycare (OR $0.097 ; 95 \% \mathrm{CI} 0.028,0.344 ; \mathrm{p}<0.001)$ and main caregiver other than biological parents (OR 6.92; 95\%CI 1.647, 29.073; $\mathrm{p}=0.003)$ with suspected $\mathrm{E} / \mathrm{BD}$. There was association of nurturing at daycare with lower risk of suspected $\mathrm{E} / \mathrm{BD}$ in 3-6 years-old children.
\end{abstract}

Keywords: Children, Daycare, Emotional and Behavioral Disorders

\section{Introduction}

Emotional and behavioral disorders (E/BD) in children are quite serious problems because they have an impact on development, as well as creating disability and reducing their productivity and quality of life. One and a half million children and adolescents in the United States are reported by their parents to have persistent emotional, developmental, and behavioral problems $[1,2]$. The prevalence of $\mathrm{E} / \mathrm{BD}$ in preschool children, as many as $74.2 \%$ of respondents were likely to experience $\mathrm{E} / \mathrm{BD}[3]$.

There are 6 main risk factors for mental emotional problems in children, namely disputes in the family, socioeconomic conditions, excessive overcrowding, crime, mothers with psychiatric disorders, and children who are not cared for at home. Children with those risk factors likely to have behavioral problems in children both externalizing (aggressive, behavior oppose) and internalization (depression, withdrawal, somatic) [4]. Psychosocial stressors are often associated with E/BD in children, such as physical illness, inadequate parenting, domestic violence, inadequate relationships with peers, and poverty $[5,6]$.

Daycare is a form of early childhood education in non-formal channels. A toddler has a very high learning ability compared to after they surpassed the age of five, therefore daycare centers must understand how to manage a child's playroom so that it has more value for the toddler entrusted [7]. Currently there are more than half of toddler taking part in childcare programs in daycare centers and this experience can affect their lives in the future [8]. The aim of 
this study is to prove the association of nurturing at daycare with suspected E/BD in 3-6 years-old children.

\section{Materials and Methods}

This cross-sectional study was done in private schools at Denpasar, Indonesia on August 2018. Our study's Ethics Committee and Institutional approval were obtained from Udayana University. This study records the suspected E/BD and its association with nurturing at daycare. Secondary outcome was the association with other factors such as age, gender, main caregiver, main caregiver's education, parents' income, and number of siblings. The data of this study were obtained from parents' interview and Kuesioner Masalah Perilaku dan Emosional (KMPE).

Suspected E/BD was assessed by KMPE, consists of 13 questions about daily behavior. Children was suspected E/BD if $\geq 1$ yes answer. Nurtured at daycare was define if the child was attending daycare in $\geq 5$ days in a week for at least 6 months.

Subjects were consecutively enrolled until fulfill the required sample size. The inclusion criterias were 3-6 year-old preschool attendant in private schools in Denpasar. The exclusion criterias were parental decline to participate, children with disabilities or special needs, and children with chronic disease requiring long-term therapy. Collected data was analyzed using computer software. Analysis was done by chi-square and logistic regression.

\section{Results}

Total 70 preschool attendants were included in our study.
Twenty-one children were excluded due to parental decline to participate. The flow chart of subjects' recruitment can be seen in Figure 1.

The subjects' characteristics are described in Table 1. Mean age of the samples is 4.46 year-old. Of 70 children, 38 children $(54.3 \%)$ had suspected E/BD. Twenty-six children $(37.1 \%)$ was nurtured at daycare. There was significant association of nurturing at daycare with suspected E/BD $(p<0.001)$. Logistic regression analysis revealed significant association of nurturing at daycare (OR 0.097 ; 95\% CI $0.028-0.344 ; \mathrm{p}<0.001)$ and main caregiver other than biological parents (OR 6.92; 95\% CI 1.647-29.073; $\mathrm{p}=0.003$ ) with suspected E/BD (Table 2).

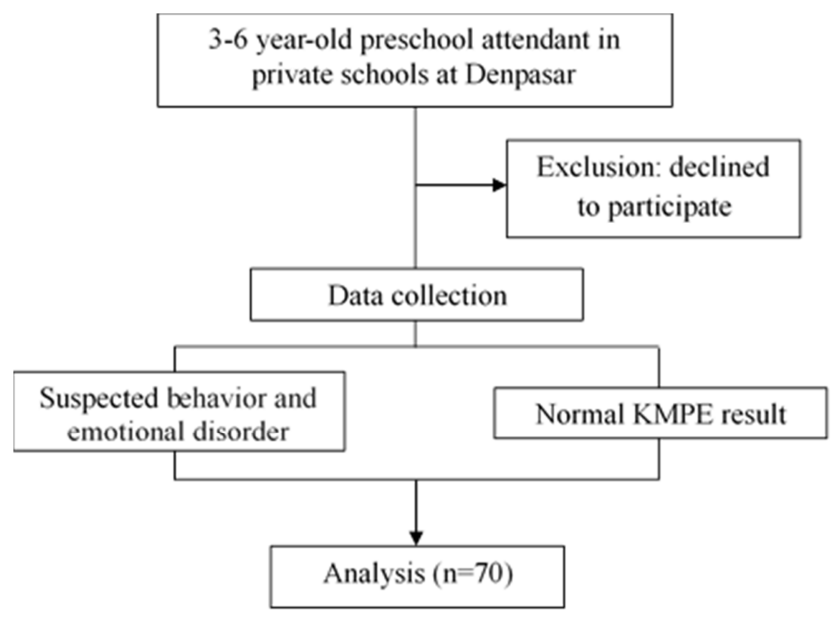

Table 1. Risk and protective factors.

\begin{tabular}{|c|c|c|c|}
\hline Variable & Suspected E/BD $(\mathrm{n}=\mathbf{3 8})$ & Normal KMPE result $(n=32)$ & P value \\
\hline \multicolumn{4}{|c|}{ Nurtured at daycare, n (\%) } \\
\hline Yes & $6(23.1)$ & $20(76.9)$ & \multirow{2}{*}{$<0.001$} \\
\hline No & $32(72.7)$ & $12(27.3)$ & \\
\hline \multicolumn{4}{|l|}{ Gender, $\mathrm{n}(\%)$} \\
\hline Male & $22(52.4)$ & $20(47.6)$ & \multirow{2}{*}{0.69} \\
\hline Female & $16(57.1)$ & $12(42.9)$ & \\
\hline \multicolumn{4}{|c|}{ Main caregiver, n (\%) } \\
\hline Other & $17(81.0)$ & $4(19.0)$ & \multirow{2}{*}{0.003} \\
\hline Biological parents & $21(42.9)$ & $28(57.1)$ & \\
\hline \multicolumn{4}{|c|}{ Main caregiver's level of education, $n$ (\%) } \\
\hline Low & $2(100.0)$ & $0(0.0)$ & \multirow{2}{*}{0.49} \\
\hline High & $36(52.9)$ & $32(47.1)$ & \\
\hline \multicolumn{4}{|c|}{ Parents income, $\mathrm{n}(\%)$} \\
\hline Below RMI & $0(-)$ & $0(-)$ & \multirow{2}{*}{ - } \\
\hline Higher than RMI & $38(54.3)$ & $32(45.7)$ & \\
\hline \multicolumn{4}{|c|}{ Number of siblings, $n(\%)$} \\
\hline$\geq 2$ & $10(62.5)$ & $6(37.5)$ & \multirow{2}{*}{0.45} \\
\hline$<2$ & $28(51.9)$ & $26(48.1)$ & \\
\hline
\end{tabular}

Abbreviation: $\mathrm{E} / \mathrm{BD}=$ emotional and behavioral disorders; $\mathrm{RMI}=$ regional minimal income.

Figure 1. Study flow chart.

Table 2. Logistic regression analysis.

\begin{tabular}{lll}
\hline Variable & OR (95\% CI) & P value \\
\hline Nurtured at daycare & $0.097(0.028 ; 0.344)$ & $<0.001$ \\
Main caregiver (other than biological parents) & $6.92(1.647 ; 29.073)$ & 0.008 \\
\hline
\end{tabular}

Abbreviation: $\mathrm{OR}=$ odd ratio; $\mathrm{CI}$ : confidence interval. 


\section{Discussion}

Emotional and behavioral disorders influenced by many contributing factors namely risk and protective factors from 4 main aspects, such as child risk factors, sociocultural, parenting and caregiving, and children's peer experiences [9]. This study found daycare as a protective factor of E/BD. There is still controversies whether daycare acts as risk or protective factor. Daycare could interfere with child attachment and lead to social maladjustment and mood instability [10-12]. The other side of the debate suggests that daycare is an essential part of children's socialization and that it may promote healthy social and cognitive development. Several studies found daycare could reduce the risk of E/BD [13-15]. Behavioral problems may be related to features reflecting the quality of the daycare, such as neglectful caregivers and lack of positive peer-interaction, as it may put children's psychosocial and cognitive development at risk [10, 16]. Contrarily, high quality daycare settings minimize sources of stress, providing personalized care, better social adaptation, and better cognitive performance among children $[14,17,18]$.

High quality daycare associated with cognitive and academic performance improvement [19]. Good daycare settings provides positive play activities with peers, as it being protective factors for emotional or behavioral problems [20]. Instability in peer relationships is a risk factor of antisocial behaviors $[9,21]$. Professional caregivers at daycare can be alternative attachment figures for a child at times when parents are temporarily unavailable [22]. Children experiencing more caregiver stability in day care have more secure relationships with their caregivers and show higher degrees of social competence [23-25].

This study found that main caregiver other than biological parents increase risk to develop E/BD. Parenting aspect have been linked to externalizing problems in middle childhood, include the extensiveness of nonparental childcare [9]. Longer hours of care in nonparental childminders or babysitters rather than good daycare centres with associated with higher rates of E/BD [19].

Externalizing behaviors are more common among boys, on the other hand, internalizing behavior is more common among girls [26]. Several studies show that child risk factors for being male is contributed to E/BD [27, 28]. Several behaviors are more common in boys than girls when looking at clinical samples [29]. However this study did not find association of gender with suspected $\mathrm{E} / \mathrm{BD}$.

There was no association of main caregiver's education with suspected E/BD in this study. Sociodemographic factors such as low socioeconomic level and low level of parental education have been associated with a higher risk of developing E/BD [26, 30, 31]. Highly educated mothers will easily absorb information about development in pre-school age children, so that knowledge about development in pre-school age children is better [32].

Number of siblings is said to be one of risk factors of developing $\mathrm{E} / \mathrm{BD}$. Children from larger families are at increased risk of emotional or behavioral problems, as four- or five-children households having higher problems compared with two-children households [19]. The number of children in the family even though the economic situation is sufficient will result in reduced attention and affection of parents received by their children, especially if the distance of the child is too close [33]. There is also direct influence between sibling rivalry events on children's mental emotional development [34]. This can have an impact on the child's development behavior.

There are limitations in this study, such as did not describe about characteristic of this daycare program and did not distinguish the parental style or family environtment that can contribute to E/BD suspicion in our samples.

\section{Conclusions}

There was association of nurturing at daycare with suspected $\mathrm{E} / \mathrm{BD}$ in 3-6 years-old children. Other factor affecting suspected $\mathrm{E} / \mathrm{BD}$ was main caregiver other than biological parents. Further studies examining the conditions under which daycare attendance influences children's emotion and behavior are needed. This is especially important in the context of governmental investments in daycare services.

\section{Conflict of Interest Statement}

The authors hereby declare no personal or professional conflicts of interest regarding any aspect of this study.

\section{Acknowledgements}

None declared.

\section{References}

[1] S. A. Rosenberg, Z. Duan, and C. C. Robinson. Prevalence of developmental delays and participation in early intervention service for young children. Pediatrics. 2008; 121: pp. 1503-9.

[2] T. Davies and T. K. J. Craig. ABC Kesehatan Mental. Jakarta : EGC, 2009.

[3] H. Brandtjen. Short and long term effects on infants and toddlers in full time daycare centers. J Prenat Perinat Psychol Health. 2001; 15 (4): pp. 1-25.

[4] C. J. Trentacosta, L. W. Hyde, D. S. Shaw, T. J. Dishion, F. Gardner, et al. The relations among cumulative risk, parenting, and behavior problems during early childhood. J Child Psychol Psychiatry. 2008; 49: pp. 1211-9.

[5] R. S. Kahn, D. Brandt, and R. C. Whitaker. Combined effect of mothers and fathers mental health symptoms on children's behavioral and emotional well-being. Arch Pediatr Adolesc Med. 2004; 158: pp. 721-9.

[6] T. Wiguna, P. S. K. Manengkei, C. Pamela, A. M. Rheza, and W. A. Hapsari. Masalah emosi dan perilaku pada anak dan remaja di poliklinik jiwa anak dan remaja RSUPN dr. Ciptomangunkusumo (RSCM), Jakarta. Sari Pediatri. 2010; 12: pp. 270-7. 
[7] F. J. Monks, A. M. P. Knoers, and S. R. Hadinoto. Psikologi Perkembangan. Yogyakarta: Gajah Mada University Press, 1989.

[8] E. A. Donoghue. Quality early education and child care from birth to kindergarten. Pediatrics. 2017; 140: pp. 1-8.

[9] K. Deater-Deckard, K. A. Dodge, J. E. Bates, and G. S. Pettit. Multiple risk factors in the development of externalizing behavior problems: group and individual differences. Dev Psychopathol. 1998; 10 (3): pp. 469-93.

[10] M. C. Geoffroy, S. M. Côté, S. Parent, and J. R. Séguin. Daycare attendance, stress, and mental health. Can J Psychiatry. 2006; 51 (9): pp. 607-15.

[11] NICHD Early Child Care Research Network. Does amount of time spent in child care predict socioemotional adjustment during the transition to kindergarten? Child Dev. 2003; 74: pp. 976-1005.

[12] E. C. Melhuish and P. Moss. Day Care for Young Children: International perspective. London: Routledge, 1990.

[13] A. I. H. Borge, M. Rutter, S. Côte, and R. E. Tremblay. Early childcare and physical aggression: differentiating social selection and social causation. J Child Psychol Psychiatry. 2004; 45: pp. 367-76.

[14] NICHD Early Child Care Research Network ans G. J. Duncan. Modeling the impacts of child care quality on children's preschool cognitive development. Child Dev. 2003; 74: 1454-75.

[15] B. Zoritch, I. Roberts, and A. Oakley. Day care for pre-school children. Cochrane Database of Systematic Reviews. 2000; 3: pp. 1-34.

[16] A. Hausfather, A. Toharia, C. LaRoche, and F. Engelsmann. Effects of age of entry, day-care quality, and family characteristics on preschool behavior. J Child Psychol Psychiatry. 1997; 38: pp. 441-8.

[17] T. Harms, R. Clifford, and D. Cryer. Early Childhood Environment Rating Scale. New York (NY): Teachers College Press, 1998.

[18] J. M. Love, L. Harrison, A. Sagi-Schwartz, M. H. van Ijzendoorn, C. Ross, et al. Child care quality matters: how conclusions may vary with context. Child Dev. 2003; 74: pp. 1021-33.

[19] V. English. Growing Up In Britain: Ensuring a Healthy Future for our Children. Britain: BMJ Books, 1999.

[20] S. Crews, H. Bender, M. Vanderwood, C. Cook, F. Gresham, et al. Risk and protective factors of emotional and/or behavioral disorders in children and adolescents: A mega-analytic synthesis. Behav Disord. 2007; 32 (2): pp. 64-77.

[21] S. Hymel, K. H. Rubin, L. Rowden, and L. LeMare. Children's peer relationships: Longitudinal prediction of internalizing and externalizing problems from middle to late childhood. Child Dev. 1990; 61 (6): 2004-21.

[22] J. C. De Schipper, L. Tavecchio, and M. van Ijzendoorn. Children's Attachment Relationships with Day Care Caregivers: Associations with Positive Caregiving and the Child's Temperament. Social Development. 2008; 17: pp. 454-70.

[23] J. C. de Schipper, M. H. Van IJzendoorn, and L. W. C. Tavecchio. Stability in center day care: Relations with children's well-being and problem behavior in day care. Social Development. 2004; 13 (4): pp. 531-50.

[24] C. Howes and C. E. Hamilton. Children's relationships with child care teachers: Stability and concordance with parental attachments. Child Dev. 1992; 63: pp. 867-78.

[25] C. Howes and C. E. Hamilton. The changing experience of child care: Changes in teachers and in teacher-child relationships and children's social competence with peers. Early Child Res Q. 1993; 8: pp. 15-32.

[26] L. Santos, F. Queirós, M. Barreto, and D. Santos. Prevalence of behavior problems and associated factors in preschool children from the city of Salvador, state of Bahia, Brazil. Revista brasileira de psiquiatria. 2016; 38: pp. 46-52.

[27] R. F. Huselid and M. L. Cooper. Gender roles as mediators of sex differences in expressions of psychopathology. J Abnorm Psychol. 1994; 103: pp. 595-603.

[28] C. Zahn-Waxler. Warriors and worriers: Gender and psychopathology. Dev Psychopathol. 1993; 5: pp. 79-89.

[29] C. L. Ibberson. Environmental factors among young children contributing to the onset of behavior disorders. Culminating Projects in Special Education. 2017; 46: pp. 1-58.

[30] L. Anselmi, C. A. Piccinini, F. C. Barros, and R. S. Lopes. Psychosocial determinants of behaviour problems in Brazilian preschool children. J Child Psychol Psychiatry. 2004; 45: pp. 779-88.

[31] Q. C. Huaqing and A. P. Kaiser. Behavior problems of preschool children from low-income families: review of the literature. Topics Early Child Spec Educ. 2003; 23: pp. 188-216.

[32] N. Azmita. Faktor dominan karakteristik ibu yang berhubungan dengan pertumbuhan dan perkembangan balita usia 2-5 tahun di wilayah kerja Puskesmas Nanggalo Kota Padang. Repository Universitas Andalas. in press.

[33] N. Howe and H. Recchia. Sibling relations and their impact on children's development. Encyclopedia on Early Childhood Development. 2006: pp. 1-8.

[34] A. C. T. Putri, S. M. Deliana and R. Hendriyani. Dampak sibling rivalry (persaingan saudara kandung) pada anak usia dini. Developmental and Clinical Psychology. 2013; 2 (1): pp. 33-37. 